\title{
POLITICAL ESSAYS \\ OF WILLIAM PATERSON
}

\author{
BY RICHARD P. MCCORMICK
}

Author of two books on New Jersey History, Experiment in Independence (1950), and History of Voting in New Jersey (1953), Dr. McCormick, Associate Professor of History at Rutgers, here introduces some little known essays by an eighteenth century political figure of New Jersey who had considerable infuence and importance in his own day.

MONG THE HOST of statesman-philosophers who shared
the historic experience of bringing a new nation into existence,
William Paterson of New Jersey held a respected position. Although not of the stature of Madison, John Adams, Jefferson, or Hamilton, he was a figure of significance on both the state and national scenes, and his influence helped to shape the American political tradition.

A graduate of the College of New Jersey (Princeton University) in the class of 1763 , he studied law and practiced his profession with indifferent success until the outbreak of the Revolution. Then he entered fully into the whig cause and was soon appointed as the first attorney-general of the new state. From that point his rise to eminence in his profession and in public esteem was rapid. By the end of the war, when he temporarily retired from public life, he had established himself as a man of unusual talents.

He was an obvious choice to attend the Constitutional Convention, where his advocacy of New Jersey's interests as a small state projected him into prominence. Next he was elected to the Senate of the first Congress, resigning that post to assume the governorship left vacant by the death of William Livingston in July, I 790. He filled this office with ability until March 30, I 793, when he resigned to become an Associate Justice of the Supreme Court of the United States. He remained on the bench until his death at the age of sixty-one on September 9, i 806.

From his early college days Paterson manifested a keen interest in literature, rhetoric, and oratory. He obviously took pride in exercising his literary talents, and from the time of the Revolutionary crisis until 
near the end of his life, he was a steady contributor of essays to local newspapers under a variety of pseudonyms, usually classical in origin. ${ }^{1}$ Many, perhaps most, of his pieces appeared in papers published in New Brunswick, where Paterson made his residence after I 783.

Forty-six such essays are contained in a folio volume of ninety-one pages that has been one of the unexploited treasures of the Rutgers University Library since it was acquired in I 90r. Written in Paterson's clear hand, these short pieces, published between I793 and I 797, deal with public affairs both state and national. Seven bearing the signature "Aurelius" appeared in Arnett and Blauvelt's Guardian; or New Brunswick Advertiser between February I 3 and April 24, I 793, at the time that Paterson was moving from the governorship to the Supreme Court. The "Horatius" articles, seventeen in number, were printed in the Genius of Liberty, $\mathcal{F}^{2}$ New Brunswick Advertiser, published by George F. Hopkins, from October, I 795, to March, I 796. Six "Hortensius" pieces ran in the Guardian from February 2 I to March 28, I 797. Nine other essays signed with various initials and seven unsigned essays presumably were published in New Brunswick papers between 1793 and $\mathbf{1} 795$, but the issues have not yet been identified.

Published below are the first five essays of the "Aurelius" series. They reveal certain basic themes in Paterson's thought that stamp him as one of the best representatives of the conservative school of whig statesmen. The Revolution, as he viewed it, was carried out for the purpose of protecting traditional rights of person and property that had been violated by British tyranny. The new order must continue to uphold those rights. But if such rights were to be maintained under a republican form of government, the citizens must be virtuous, factionalism must be avoided, the laws must be obeyed, and popular forces must be held in check. In the political definitions of those times, Paterson was an ultra-Federalist, although he was not a "party man" and would have refused to wear a label. His ideas, which were representative rather than original, were readily translatable into

${ }^{1}$ Manuscript originals of many such essays are in the collections of Paterson's papers in the Rutgers University Library and the Princeton University Library. Other copies of original pieces are in the Bancroft Transcripts, New York Public Library. No serious effort has yet been made to identify Paterson's newspaper writings. 
legal garb, and through his judicial decisions they entered into the main stream of our American political tradition. ${ }^{2}$

\section{[On Candid and Liberal Sentiments] ${ }^{3}$}

In taking a view of men and things, it is of moment to keep in exercise candid and liberal sentiments. This is proper in all situations, because we cannot otherwise form right opinions. With the man of religion it is an Act of duty, and with the gentleman a point of honor to appreciate characters and actions by the scale of principle and justice. This mode of procedure is on all hands agreed to be equitable and useful in private life, and a little attention will evince it to be at least equally so in public. In free governments, where men enjoy the right of judging for themselves, diversity of sentiment respecting public men and measures must be expected, and is, indeed, unavoidable. This diversity, however, is attended with good or bad effects according to the principle from which it flows. If the agent be an honest and candid inquirer, if his object be truth and information, he will be ever open to conviction, and, when convinced, will think it no dishonor to retract, and acknowledge his error. But, on the contrary, if his mind be darkened by prejudice, be guided by selfish views, or actuated by party spirit, his opinions, however erroneously formed, no course of reasoning nor of facts can induce him to forego. He may be refuted, but will never be convinced; truth may dazzle him by its brightness, but will never irradiate or cheer. To attempt conviction under such Circumstances would be Labor unprofitably bestowed.

\section{Aurelius}

2 The standard biography, William Paterson of New Jersey (Fair Lawn, N.J., 1933), by Gertrude S. Wood, is not worthy of its subject. For a discerning brief sketch, see Julian Boyd's chapter in Willard Thorp, ed., The Lives of Eighteen from Princeton (Princeton, I 946). The Rutgers University Library has a large collection of Paterson's papers, in addition to the essays described above.

3 This initial essay of the series appeared in the Guardian, February 13, I 793. The three numbers that follow were printed on February 20, February 27, and March I3, I 793 . 


\section{[On a Well Regulated Militia]}

A well-regulated militia is considered as essential to the preservation of civil Liberty. What, indeed, is a militia but the people themselves prepared to act as soldiers for the purpose of resisting oppression and securing their rights. To be prepared for war is the way to prevent it; to be ready in arms to meet and resist tyranny never fails to deter its approach. Tyrants dread freemen, when freeman not only have arms in their hands, but know how to use them. Discipline, aided and enforced by the energy and impulse of freedom, is irresistible. Even men, untutored in the art of war, but resolved to be free or die, have achieved wondrous things. Witness Switzerland and the Netherlands; witness America and France. The citizens of New Jersey are too enlightened to stand in need of any dissertation upon the utility and importance of a well-organized and disciplined militia. Congress have begun this interesting work, the legislature have pursued it; but it depends upon you, my countrymen, to finish it. ${ }^{4} \mathrm{By}$ the constitution it is ordained, that the men of every company shall elect their own officers; shortly you will be called upon to execute this important duty. Much depends upon its. proper discharge; your own honor, your own liberty, and the transmission of that liberty to generations unborn. What persons should be the object of choice, with what vices uncontaminated, and with what virtues and talents adorned? Pause; the questions are weighty; think upon them carefully and often, for well they deserve your most serious consideration. Choose not a drunkard; he is wedded to his bottle and glass, and fit for nothing but to swallow whiskey and grog. Call upon him to forsake his beloved liquor, to forswear the bowl, and to resume his original manhood; the call is vain; he would sooner forsake and forswear friends, and relations, family and country, than forego one drop of the intoxicating draught; he is useless to society, worse than useless, his example is bad, and, if in office, dreadfully influential and contagious. More is to be feared from a drunken officer than from a host of foes. Alas! that so many men of promising parts and amiable dispositions should fall a sacrifice

\footnotetext{
${ }^{4}$ Congress provided for the establishment of a uniform militia system in the act of May 28, I 792. The corresponding New Jersey law was enacted November 30, 1792.
} 
to this debasing and dead-doing vice. Avoid, therefore, the drunkard; shun him as the pestilence. Choose not a man of indolence and sloth. The life of an officer, when in the field, is a life of activity, of vigilance, and toil; he rises early and late takes rest; duties are continually pressing upon him, when one is discharged, another awaits; he is always doing and never done. Is a man, made up of nature's heaviest mould, to whom thought is labor, and activity is death, fit for a station, which requires unremitting diligence, constant energy, and the most strenuous exertions? Choose not an ignorant man. Can he teach others, who stands in need of being taught himself? A person of an over-easy and indulgent temper is not formed for an officer; his pliability, and, perhaps, fondness to please, relax discipline, and destroy subordination; ductile and obsequious, his men work him into any shape; he yields to their solicitations, grants what they ask, and wills what they wish. What an inversion of order! Instead of leading, he follows, and instead of commanding, obeys. Avoid such a character, if you wish to be expert in military exercise, to be useful to the public, or respectable in the eyes of your fellow-citizens. Above all, shun and despise the man, who attempts to gain votes by dealing out bottles of brandy and bowls of grog, or by other improper means and base arts. Can the spirit of freemen endure such conduct, or suffer the perpetrator to rise into office by the profuse distribution of spiritous liquors and strong drink? Every attempt of this kind resent and indignantly repel. Esau sold his birthright for a mess of pottage. Baser ye, if you barter your suffrages for a glass of brandy, or a can of grog. Choose the sober and sensible, the cool and brave, the steady and prudent man; the man, who knows or is capable of knowing his duty, and will discharge it faithfully; the man, who is collected in the midst of danger, and firm and decided in every state of things; the man, who has a becoming degree of pride, and is ambitious to excel, who courts distinction, has the honor of soldiery at heart, and makes their glory his own; the man, who possesses an elevating fervor of sentiment, whose spirit animates, and whose ardor warms. Bear in mind, I beseech, that on the selection of proper characters for office depend [sic] the formation and discipline, the arrangement and evolutions, of military bodies. A mistake in this particular is ruinous and beyond repair. With you rests the power of Choice; with this power are intimately connected the honor \& safety, the 
military state and fame of every corps; in short, the establishment of an effective Militia depends upon the election of proper officers or, in other words, upon your own suffrages. Highly, then, it becomes every individual to examine the qualifications of the respective candidates before he proceeds to vote. Permit me to conclude with a short address to such as are exempted from militia duty on the score of age. Though beyond the age $e^{5}$ prescribed for military life, still much is in your power to effect. By advice you can aid, and by your presence encourage. Readily impart both. The military spirit beats strong and high; suffer it not to abate. Interest and duty unite in the call and say, catch, oh! catch! the rising ardor, cherish and fan it into a general flame. Contemplate, again and again contemplate, the late revolution, in which you bore an active part; arduous, and bloody, and dubious was the conflict, and many and gloomy were the hours, that passed over your heads. Dark days may again return; clouds may again obscure our political horizon; again may the oppressor arise, and attempt to enslave. Your sons may be called upon to act the part, which you have so gloriously performed. You have given them freedom; instruct them how to preserve the inestimable gift. Bid them, arm; bid them learn the use of arms. Say, with these weapons we fought our way to liberty and independence; gently sinking into the vale of life, we now resign them to you our sons; and, sacred to freedom! may they never, never tarnish in your hands. No, never to tarnish, reiterate and vow the generous and ardent youths.

Aurelius

\section{III}

\section{[ON Political Parties]}

"Party is the madness of many for the gain of a few." This remark, made by a man of genius and experience, has ripened into a proverb. Who can set bounds to the spirit of faction? What mortal can still the raging tempest, or stay the headlong cataract? The intemperate zeal of party drives with the impetuosity of a whirlwind, and upturns every thing in its course. It stickles at nothing. Truth is falshood [sic], and falshood is truth, as may best serve a present turn, or the

\footnotetext{
${ }^{5}$ Enrollment for militia duty was required of men between the ages of eighteen and forty-five.
} 
politics of the moment. Observe the rule by which a violent partyman measures characters. Is a person a believer in his political tenets and creed, and loud and warm in their support? His praise is sounded far and wide, his virtues are blazoned, and even his defects are, by the magic touch of party, turned into beauties. Whereas if he happens to be of another and opposite side, he is a mere mass of corruption, weakness, and villainy; a very compound of all the vices, that degrade human nature. Imagine a party ardently set and busily employed to drive from office a man, whom they dislike, because, perhaps, he cannot be moulded to their views. How they labor and toil in the dirty work of obloquy and fiction. What falshoods and lies are engendered, how wofully [sic] are facts misrepresented, and what little arts are made use of for the purpose of deceiving the people, and inflaming the public mind. If hunted out of office, will any hostile traducer fill it better, or act with more honesty and fairness.-Believe me, my countrymen, that no detractor is fit for public life or employment. It is a sad proof of the depravity of human nature, that truth never travels with half the speed of falshood, nor meets with so current and cordial a reception. If this is the case in private life, what must it be in public, where so many active and interested spirits are engaged to help on a political or rather party lie. It is, however, an act of justice to observe that the citizens of the United States, having the means of information more within their reach, being in general better instructed, and in happier circumstances than any other people whatever, are, of course, not prone to run into violent measures, or to be heated and worked upon by factious and designing men. The newspapers, which are daily and weekly printed and circulated in every state of the union, are the vehicles of much political light and useful information. Congress have not been wanting in attention to this important subject; for we find, that, in consequence of their late act, ${ }^{6}$ the newspapers are now transmitted more generally, and with greater certainty and speed, than at any former period. For supporting good government, cherishing republican principles, and promoting the cause of virtue, and of freedom, schools and seminaries of learning are of primary importance. The mind without literature or science is in a rude and dark state, and incapable of high or useful

6 The act referred to was probably that of February 20, I792, which provided preferentially low rates for the carrying of newspapers by the postal service. 
exertions; even genius, uncultivated, loses half his force; he soars, but with unequal wings. Ages have passed away, generations have rolled on in rapid succession, ere the rights of man were ascertained or understood. Seek ye the reason? Man was ignorant. What can be expected from uninformed and ignorant minds? They know no country, and have no patriotism. Enough, if they know the spot on which they were born and rocked, that is their country; enough, if they know and consult the little interests of the neighbourhood in which they live and move, that is their patriotism. But of country, which comprehends towns, counties, and states and their numerous inhabitants, which comprehends thousands and millions of men as well as the earth on which they live, and of patriotism, which views those thousands and millions with equal eye, and clasps them all in the same generous embrace; of such a country and of such patriotism what do they know. Persons ignorant and uninformed are easily imposed upon and led astray; they are unable to detect error, have no resources within themselves, and generally repose implicit confidence in others; they are the fit, and indeed usual instruments in the hands of designing men to serve the purposes of party, or to work out the ruin of a state. Without mental and moral improvement, neither order, nor republicanism, nor civil liberty can long be preserved. Ignorance is freedom's worst foe.

Aurelius

\section{IV}

\section{[ON RePublicanism]}

In my last paper, I took notice, that the citizens of the United States are better instructed and informed, and in happier circumstances than any nation or people on earth. The condition of a people with respect to property is a matter of importance in a political view. Some theoretical politicians, who frame systems without adverting to the actual state of things, and the economy of providence, contend, that republicanism requires an equal distribution of property, and for this purpose that Agrarian laws should be passed from time to time. The notion is wild; it cannot be reduced to practice, and, if it could, would be attended with more pernicious than salutary effects. Republicanism delights in virtue, which is an active principle, and excites 
to honesty and industry, and of course is opposed to idleness and sloth. The equalizing of property by the strong hand of power would be a tax upon the active and industrious man for the support of the sluggard, who, like the drone, would live upon the earnings of others without bringing anything into the common stock. That nation, however, bids fairest to attain the summit of political prosperity and happiness, in which property, especially if it be of a landed nature, is pretty equally diffused among the people. Land is a species of property more safe than any other, because less liable to be affected by revolutions and wars, by political conflicts, popular commotions, or disastrous casualties of any kind. Land yields to its industrious owner $\&$ cultivator all the necessaries and conveniencies of Life, which raises him above the fear of want, and far above the abject state of a precarious dependent. This is a situation, which naturally produces independence of sentiment, emboldens the spirit, and invigorates the mind. The freeholder is truly an independent Man. It is a pleasing circumstance; that the bulk of the citizens of the United States are proprietors of the soil on which they live; they work their own ground and enjoy the fruits of their labor, under laws made by men of their own choice, and under one general system of government honestly and ably administered. Happy People! May neither foes at home nor foes abroad disturb this your rare and high felicity! With the late revolution was introduced a change or rather renovation of legal principles so far at least as respected real estates. The law of descent or hereditary succession has been revised and altered, and made to correspond with the genius of the government under which we live. The right of primogeniture is nearly done away, and landed property, in case of intestacy, is apportioned with some degree of equality among the children or other relatives of the deceased. The eldest son is not now, except in particular instances, sole heir to the exclusion of the rest. The doctrine of entails, which originated in aristocratic pride and domination, and was intended by the feudal lords to prevent forfeitures and to perpetuate possessions in families, has sunk before the enlightened policy of the present republican age. Such alterations meliorate the condition of man, are descriptive of the American character, and favorable to civil liberty and order. I cannot close without observing, that the United States, in another point of view, possess an advantage, which was never enjoyed by any 
republic of antient or modern times. The present confederacy embraces a number of States, which collectively extend over an immense tract of country. It is not probable, that the spirit of faction, however restless and turbulent, will rage in every state or part of the union at the same juncture or point of time. Wonderful must be the coincidence of circumstances and combination of causes, which will in a moment produce so general an effect.

\section{Aurelius}

\section{V}

\section{[On Parties and the Constitution] ${ }^{7}$}

To mark the course of parties, and the appellations and virtues, which they assume, and the calumny and vices, which they bestow on others, is amusing or disgustful, according to one's present humour or cast of mind. When the constitution of the United States was published for consideration and adoption, many and violent were its enemies and friends, and most unmercifully did they belabour one another. Every part of it was the subject of discussion. The presidential office was severely animadverted upon. The ken of politicians saw dreadful things; saw the fetus of a monarch, saw an infant Hercules in his cradle; and, God bless us! saw a king. Yes, good people, saw it grow into a monster of a king. And yet, passing strange, we are alive, still alive, and alive like to be. The Senate was a very house of lords; where, sad to tell, the little states were lords as well as the great. Why is it not plain, that these devils of lords should be of size exactly in proportion to the size of the several states? Can anything be more absurd than to see cheek by jowl a Rhode Island lord, and Massachusetts, a Delaware lord, and Virginian. Besides, it is a million to one, that these little lords will slip their hands into the pockets of the great lords, and purloin their pelf; nay, perhaps, in an evil hour, knock out their brains, and with the self-same mortal knock, knock down liberty. Ah! see poor liberty expires. For, my fellow-citizens, it is clear as day, that liberty cannot dwell in little states, or among little folks; she loves great folks, and great states, where she can roam at large for hundreds and thousands of miles,

7 This piece, although a part of the "Aurelius" series in the manuscript, does not appear to have been published with the others. 
and no one to make her afraid. The manner in which representation was formed did not pass free of censure. It was objected, that the negroes, though slaves, were taken into the account. What a pother and deal of fuss do some people make about nothing. Slaves are men, and also a species of property, and therefore of double value in a land of liberty. The judiciary system had its foes; it was unfriendly to liberty, and repugnant to the spirit of a free people. How so? why it tended to make men honest, perform contracts, do justice, and pay their debts. What a system of tyranny! Death, that the freeborn soul should be fettered with such trammels. What is freedom, son of man, what is freedom, but to act or not to act, to do or not to do, to perform or not perform, to pay or not to pay, just as one pleases. All compulsion is odious; but to compel men to pay their debts is downright oppression and not to be endured. To note all the objections that were made would take volumes, and be endless. The constitution, with all its vices, was adopted; the people judged for themselves, considered it thoroughly, and made it their own. It became their child; but if we are to believe certain writers there never was such an ill-begoten [sic] and ill-shapen brat produced upon this our earth; it wants a world of licking before it can be lickt into shape. Some hopes, however, may be entertained from the prodigious number of lickers, that are constantly at work. Various parties, it is pretended, have arisen under the present government. The names, which they have occasionally assumed, or conferred on one another, are many and curious. Look at the list; and you will find, aristocrats, democrats, and mobocrats, monarchy-men, equalitymen, liberty-men, and republicans, to say nothing of federalists and anti-federalists. The eastern people, it is said, are all monarchy-men and aristocrats; while the mighty land-holders, and slave-holders of the south are sure and fast friends to equality and the rights of man. Awake, gentle reader, and shake thyself; rub thine eyes; rub them again and again; for the thing is miracllous [sic] to behold. Well, what see you, and how do you believe? Leaving every one to believe as he pleases, permit me to conclude with my own belief. I verily believe, that we have suffered more, and have more to dread from the Hessian $\mathrm{fly}^{8}$ than from all the monarchy-men and monarchy

8 The Hessian fly made its appearance in New Jersey toward the end of the Revolution and within a decade so devastated the wheat crop that wheat growing had to be abandoned in most parts of the state. American Museum, I (I 787), pp. I33-38, 29 I-93, 456-59. 
makers, that now exist or ever will exist in the United States. What a mercy, that these destructive and evil-winged flies were not generated by the present government, or present men in office and power.

Aurelius

Although the five essays reprinted here are broadly indicative of the main trends of Paterson's political thought, they do not adequately suggest the wide range of topics on which he expressed himself. The remaining forty-one essays are no less interesting, both for the illumination they cast on contemporary events and the insights they afford into the mind of a prominent statesman. The remaining two numbers of the "Aurelius" series, for example, are devoted to analyses of the powers of the governor and the role of the judiciary in New Jersey. The essays that are identified only by initials deal with the need for education, the desirability of housing beggars in workhouses, the blessings of the Constitution, the importance of the Sabbath, the dangers of foreign influence in the government, and the evils of excessive partisanship. Several of the "Horatius" numbers set forth Paterson's views on the Jay Treaty and other contemporary developments in the area of foreign affairs. Others review retrospectively some of the leading political acts of the I 780 's in New Jersey. The six "Hortensius" pieces relate exclusively to the need for reforming the state's election laws, and five unsigned articles urge that the debates in the state legislature should be published in the newspapers.

Students of America in the early Federal period will be amply repaid by an investigation of these frank essays of William Paterson. In time, perhaps, this distinguished Justice from New Jersey will receive the recognition he merits as a political philosopher, lawyer, and statesman. 